\title{
ENVIRONMENTAL ADAPTATION OF TROPICAL PASTURE PLANTS
}

\section{R. HUMPHREYS}

Head, Department of Agriculture, University of Queensland, St Lucia, Australia 
(C) L. R. Humphreys 1981

Softcover reprint of the hardcover 1st edition 1981

All rights reserved. No part of this publication may be reproduced or transmitted, in any form or by any means, without permission

First published 1981 by

Scientific and Medical Division

MACMILLAN PUBLISHERS LTD

London and Basingstoke

companies and representatives

throughout the world

British Library Cataloguing in Publication Data

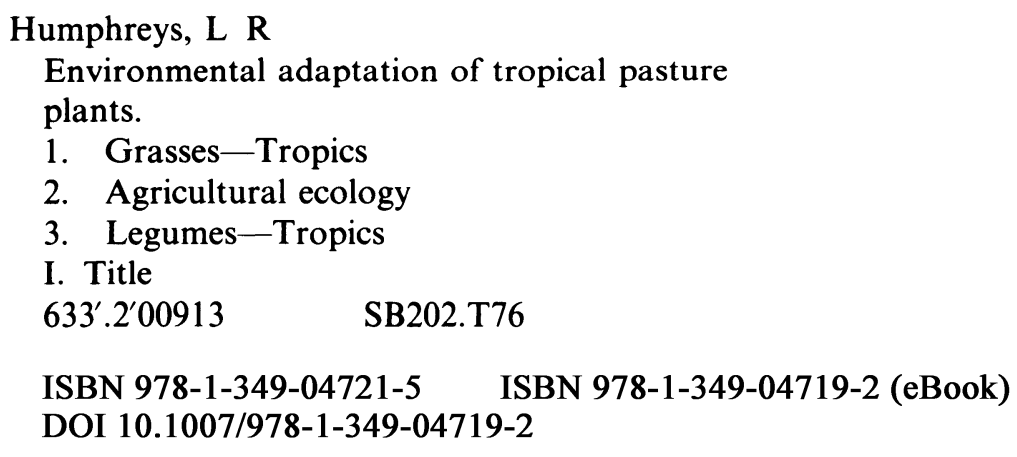

To I. L. H. 


\section{Contents}

Preface

Acknowledgements

1. INTRODUCTION 1

2. PATTERNS OF GEOGRAPHICAL DISTRIBUTION 7

2.1 The Rationale for Plant Introduction 7

2.2 Grass Distribution $\quad 10$

2.3 Legume Distribution $\quad 14$

2.4 Origins of Domesticated Pasture Plants 15

Grass domestication $\quad 15$

Legume domestication $\quad 17$

2.5 Current Use of Planted Species in Relation to Climate 18

3. THE CAPACITY FOR GENETIC VARIATION 29

3.1 Self-fertilised Legumes 32

3.2 Cross-fertilised Legumes 40

3.3 Open-pollinated Grasses $\quad 41$

3.4 Apomictic Grasses 43

4. SURVIVAL MECHANISMS IN TROPICAL PASTURE SPECIES 49

4.1 Flowering and Seed Formation 50

Climatic controls of flowering and seed formation 51

Juvenility 51

Variation in influential day length $\quad 52$

Photoperiod response types $\quad 54$

Interaction of photoperiodic requirement with temperature 56

Moisture effects on flowering $\quad 57$

Seed formation $\quad 58$

Effects of the climatic control of flowering on plant
distribution

Effects of soil fertility on flowering and seed formation $\quad 62$

4.2 Soil Seed Reserves 63

Seed dispersal 63

Seed longevity $\quad 64$ 
Seed dormancy $\quad 65$

Seed-coat effects $\quad 66$

Embryo dormancy $\quad 71$

4.3 Seedling Regeneration $\quad 73$

$\begin{array}{ll}\text { Seed vigour } & 73\end{array}$

Environmental influences on seedling regeneration 75

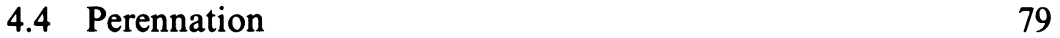

$\begin{array}{ll}\text { Crown structure } & 80\end{array}$

Root growth, energy accumulation and bud dormancy 81

5. CLIMATIC HAZARDS TO SURVIVAL 83

$\begin{array}{lll}5.1 & \text { Drought } & 83\end{array}$

Incidence $\quad 83$

Comparative plant resistance to drought 86

Basis of adaptation to drought $\quad 88$

Mechanisms of drought avoidance $\quad 88$

Drought tolerance $\quad 92$

$\begin{array}{ll}5.2 \text { Chilling } & 95\end{array}$

Incidence $\quad 95$

Comparative plant resistance touchilling 96

Basis of adaptation to chilling $\quad 99$

$\begin{array}{llr}5.3 \text { Frost } & 100\end{array}$

Incidence $\quad 100$

Comparative plant resistance to frost 101

Basis of adaptation to frost 102

6. PLANT RESPONSE TO EDAPHIC AND PHYSIOGRAPHIC HAZARDS 107

6.1 Flooding and Impeded Drainage 107

Incidence and effects $\quad 107$

Comparative plant tolerance of flooding $\quad 109$

Mechanisms of tolerance $\quad 112$

6.2 Soil Acidity and Mineral Toxicity 113

Direct effects of $\mathrm{pH} \quad 115$

Calcium and molybdenum availability $\quad 118$

Aluminium toxicity $\quad 119$

Manganese toxicity $\quad 123$

$\begin{array}{ll}6.3 \text { Salinity } & 124\end{array}$

Occurrence and effects of salinity $\quad 124$

Comparative tolerance $\quad 126$

Mechanisms of tolerance $\quad 127$

6.4 Soil Textural Effects 131

7. PLANT RESPONSE TO BIOTIC HAZARDS 133

7.1 Grazing and Cutting 133 
Defoliation, excretion and treading 133

$\begin{array}{ll}\text { Avoidance of defoliation } & 135\end{array}$

$\begin{array}{ll}\text { Accessibility of forage } & 138\end{array}$

The physical nature of forage $\quad 138$

Plant replacement by seedlings 139

Flowering and seed formation $\quad 140$

Soil seed reserves $\quad 143$

Seedling regeneration 145

Maintenance of growth rate under defoliation 145

Genetic differences in growth rate $\quad 146$

Plant capacity for tillering $\quad 146$

The maintenance of leaf area $\quad 147$

Nitrogen fixation $\quad 151$

Plant longevity and survival under stress $\quad 153$

The accumulation of non-structural carbohydrate $\quad 154$

Energy status and regrowth $\quad 155$

$\begin{array}{ll}7.2 \text { Burning } & 157\end{array}$

Effects of grassland fires $\quad 158$

Resistance to fire $\quad 159$

$\begin{array}{ll}7.3 \text { Diseases and Pests } & 160\end{array}$

Effects of diseases and pests on persistence and yield 160

Environmental modifications to disease and pest outbreaks 162

Comparative field resistance 164

8. PLANT VARIATION IN GROWTH RATE 169

8.1 Growth of $\mathrm{C}_{4}$ and $\mathrm{C}_{3}$ Tropical Plants 170

Levels of yield $\quad 170$

Photosynthetic processes and plant anatomy $\quad 170$

Response to illuminance 173

Response to carbon dioxide supply $\quad 174$

8.2 Growth of Species and Cultivars 176

Temperature dependence of growth 176

$\begin{array}{ll}\text { Sward structure } & 179\end{array}$

Tillering, leaf growth and leaf senescence $\quad 180$

$\begin{array}{ll}\text { Distribution of assimilate } & 182\end{array}$

9. PLANT INTERRELATIONS: COMPETITION AND

INTERFERENCE $\quad 185$

9.1 Light and Plant Interrelations 186

Comparative tolerance of shade $\quad 187$

Plant capacity for shading companion species $\quad 189$

9.2 Water and Plant Interrelations 190

9.3 Mineral Nutrients and Plant Interrelations 192

Plant extractive capacity, nutrient requirement and response 193 
Potassium

193

Phosphorus 196

Nitrogen

199

Symbiotic nitrogen fixation

202

Rhizobial strain specificity and effectiveness

202

Legume nitrogen accretion and legume competition with

203 grasses for nitrogen

205

9.4 Allelopathy

206

10. CONCLUSION

211

10.1 Adaptation of Cultivated Tropical Pasture Plants

211

10.2 Deficiencies of Adaptation

References

221

Index of Plant Names

253

Subject Index 


\section{Preface}

This book has been written for students who have completed an elementary course in pasture science, and for pasture workers who have an interest in plant adaptation.

A few books have been published which catalogue the morphological features, adaptive characters and agronomic utility of the individual grass and legume species grown in tropical pastures. This book has a different objective. It does not attempt an encyclopaedic coverage of plant characteristics, but seeks to establish the principles of ecological success for pasture plants used in the diverse environmental conditions of tropical farming systems.

The introductory chapters discuss the patterns of geographical distribution of tropical pasture grasses and legumes, the origins of the domesticated plants, and their capacity for genetic variation. The persistence of plant yield depends upon plant replacement through the cycle of flowering, seed formation, accretion to soil seed reserves and seedling regeneration, or upon perennation; factors influencing these pathways are described.

The main themes of the book are concerned with the dependence of ocological success upon plant resistance to environmental stress, and/or upon the superior capacity of plants to gain a greater share of environmental resources for growth through interference with their neighbours. There is considerable variation available among cultivated tropical pasture plants in the mechanisms of avoidance or tolerance of environmental stresses. These stresses include those associated with climate (drought, chilling, frost), with edaphic and physiographic situation (flooding, impeded drainage, soil acidity, mineral toxicities, salinity and soil texture), and biotic hazards (grazing and cutting, burning, pests and diseases). The dominance of plants in mixed pastures is discussed in terms of genetic variation in growth responses and in the capacity for interference with the availability of light, moisture and nutrients to companion plants, or for interference through allelopathy. These principles are illustrated by reference to concrete findings from pasture research carried out in northern Australia and in other tropical and subtropical countries.

The scientific advances of the past 20 years in the field of tropical pasture science have opened new possibilities for animal production and for the stabilising of ecosystems. The development of seed and planting material of improved pasture varieties which are well adapted to specific environmental 
niches is the single innovation most easily absorbed into tropical livestock farming systems and most required for gains in productivity.

St Lucia, Australia

L. R. H. 


\section{Acknowledgements}

I am most grateful for advice and help from:

C. S. Andrew, P. J. Argel, C. J. Asher, G. M. Behncken, E. J. Britten, D. F. Cameron, M. M. de Carvalho, R. C. Colbran, J. K. Cull, J. P. Ebersohn, D. G. Edwards, D. L. Garden, T. A. Gibson, R. S. Greber, B. Grof, J. B. Hacker, A. C. Hansen, R. L. Harty, J. M. Hopkinson, E. M. Hutton, R. L. Ison, D. A. Ivory, R. M. Jones, B. Kenyon, T. Kipnis, A. E. Kretschmer, M. M. Ludlow, J. J. Mott, A. Pott, G. S. Purss, E. H. Roberts, M. Seithlheko, M. E. Siregar, H. J. Taylor, L. E. Tergas, P. C. Whiteman, R. J. Williams, G. L. Wilson, L. Winks and N. D. Young.

I am indebted to the Australian-American Education Foundation, the University of California, Davis, and the Australian Meat Research Committee, for support. 